\title{
FULLY HUMAN BEING PADA REMAJA SEBAGAI PENCAPAIAN PERKEMBANGAN IDENTITAS
}

\author{
Nur Astuti Agustriyana ${ }^{1)}$, Insan Suwanto ${ }^{2)}$ \\ 1) Universitas Negeri Semarang, Semarang, Indonesia \\ E-mail:tria_02@ymail.com \\ ${ }^{2)}$ Prodi Bimbingan dan Konseling STKIP Singkawang, Singkawang, Indonesia \\ E-mail: insansuwanto@gmail.com
}

\begin{abstract}
Abstrak. Tulisan bertujuan mengetahui keterkaitan antara fully human being dengan perkembangan identitas pada remaja. Pada artikel ini dijelaskan tentang tahapan perkembangan remaja, teori Gestalt terkait fully human being serta faktor-faktor yang mempengaruhi fully human being pada remaja.
\end{abstract}

Kata Kunci: Fully Human Being; Remaja

\section{Pendahuluan}

Setiap manusia berkembang sesuai dengan tahapan perkembangan dangan tugas yang harus dilaksanakan oleh masing-masing individu. Usia sering kali menjadi patokan dalam menentukan keberhasilan beserta tingkat perkembangan manusia. Tahapan perkembangan manusia memiliki keterkaitan yang sangat dekat dengan tugas perkembangan. Tahapan perkembangan manusia memiliki berbagai tingkatan yang dimulai saat manusia tersebut lahir hingga manusia tersebut tiada. Setiap ahli memiliki beberapa macam tahapan perkembangan manusia tergantung pada aspek masing-masing tahapan perkembang, yaitu aspek kognitif, afektif dan perilaku.

Dilihat dari aspek perilaku, maka tahapan perkembangan manusia terbagi ke dalam delapan tahapan perkembangan yaitu tahap perkembangan kepercayaan vs kecurigaan, hingga tahap integritas vs keputusasaan. Dari delapan tahap perkembangan manusia, tahap adolescence (remaja) menjadi tahap yang berbeda dari tahap-tahap yang lain. Perbedaan itu disebabkan oleh adanya perubahan perkembangan fisik maupun psikis pada individu yang membawanya kepada perubahan perilaku. Masa Remaja (adolescence) dimulai saat manusia berada pada masa puber dan berakhir pada usia 18 atau 20 tahun.

Menurut Santrock [1] remaja merupakan salah satu tahapan perkembangan manusia dengan ciri manusia tersebut sering mengalami masa krisis identitas dan ambigu. Hal yang demikian menyebabkan remaja menjadi tidak stabil, agresif, konflik antara sikap dan perilaku, kegoyahan emosional dan sensitif, terlalu cepat dan gegabah untuk mengambil tindakan yang ekstrim. Dari sifat remaja yang mudah mengalami kegoyahan emosional dan gegabah tersebut menyebabkan remaja tidak mudah untuk mempertahankan emosinya yang positif sehingga sebagian besar individu yang masuk pada tahap perkembangan remaja sering menunjukkan perilaku agresif baik kepada teman, orang tua maupun kepada orang lain yang lebih muda.

Selanjutnya Erikson [2] menambahkan bahwa tugas perkembangan remaja yang paling penting adalah pembentukan identitas diri. Selama masa ini remaja mulai merasakan suatu perasaan tentang identitas diri, perasaan bahwa dirinya adalah manusia yang unik. Manusia mulai mempelajari sifat-sifat yang melekat pada dirinya sendiri, tujuan masa depan, kekuatan dan hasrat untuk mengontrol nasibnya sendiri. Masa pencarian identitas diri terjadi pada masa remaja karena masa remaja merupakan masa peralihan pembentukan identitas yang akan berlangsung sampai masa remaja akhir. Menurut Marcia [2] terdapat minimal tiga dari aspek perkembangan remaja muda yang penting untuk mengidentifikasi pembentukan identitas. Remaja muda tersebut harus yakin memperoleh dukungan orang tua, harus mencapai prakarsa (sense of industry) dan harus mampu melakukan refleksi diri yang menyangkut masa depan.

Menurut Corey [3] Rogers membagi teori kepribadiannya ke dalam 4 bagian utama yang salah satunya adalah potensi untuk tumbuh dan belajar serta memaknai kondisi-kondisi sebagai fungsi penghargaan positif dan penghargaan diri. Potensi untuk tumbuh dan belajar serta 
memaknai kondisi merupakan bentuk cara untuk mencapai refleksi diri ke masa depan. Bagian kepribadian paling utama yang berfungsi sepenuhnya disebut dengan fully functioning person atau fully human being. Keterbukaan terhadap pengalaman, percaya pada dirinya sendiri, evaluasi diri dari sumber internal dan keinginan untuk selalu berkembang menjalani proses sebagai bentuk cara yang dilakukan dalam mencapai refleksi diri tentang masa depan. Cara yang telah disebutkan diatas merupakan ciri-ciri individu yang memiliki fully functioning being.

Ciri-ciri tersebut sesuai dengan yang diungkapkan oleh Ryff \& Keyes [4] fully function being masuk dalam dimensi psychological Well Being bagian dari kemandirian yang mengungkapkan bahwa fully function being menunjukkan orang yang memiliki pandangan pribadi tentang evaluasi mengenai dirinya. Maka remaja yang memiliki fully function being berarti remaja tersebut mampu secara mandiri percaya pada dirinya tentang potensi yang dimiliki serta mengevaluasi apabila terjadi kekurangan untuk mencapai identitas diri yang diharapkan.

\section{KAJIAN TEORI}

Masa remaja adalah masa transisi dalam rentang kehidupan manusia, menghubungkan masa kanak-kanak dan masa dewasa [2]. Menurut Rice [5] masa remaja adalah masa peralihan, ketika individu tumbuh dari masa anak-anak menjadi individu yang memiliki kematangan. Pada masa tersebut, ada dua hal penting menyebabkan remaja melakukan pengendalian diri. Dua hal tersebut adalah, pertama, hal yang bersifat eksternal, yaitu adanya perubahan lingkungan, dan kedua adalah hal yang bersifat internal, yaitu karakteristik di dalam diri remaja yang membuat remaja relatif lebih bergejolak dibandingkan dengan masa perkembangan lainnya (storm andstress period). Dalam tahapan perkembangan remaja menempati posisi setelah masa anak dan sebelum masa dewasa.

Menurut Hurlock [6] menjelaskan bahwa semua tugas perkembangan pada masa remaja dipusatkan pada pusaka penanggulangan sikap dan pola perilaku yang kekanakkanakan dan mengadakan persiapan untuk menghadapi masa dewasa. Tugas-tugas yang dimaksudkan tersebut adalah menerima keadaan fisiknya, menggunakan tubuhnya secara efektif, mencapai kemandirian emosional dari orang tua dan orang-orang dewasa lainnya, mengembangkan konsep keterampilan intelektual yang sangat diperlukan untuk melakukan peran sebagai anggota masyarakat. Selanjutnya Kay [7] menambahkan tugas-tugas perkembangan remaja adalah menerima dirinya sendiri dan memiliki kepercayaan terhadap kemampuannya sendiri, memperkuat self-control (kemampuan mengendalikan diri) atas dasar skala nilai, psinsip-psinsip, atau falsafah hidup dan meninggalkan reaksi penyesuaian diri (sikap/perilaku) kekanak-kanakan.

Menurut Corey [3]fully human being memiliki lima sifat khas yang berfungsi sepenuhnya yaitu keterbukaan pada pengalaman dengan menunjukkan penerimaan diri secara emosional baik yang positip maupun negatif, kehidupan eksistensial dengan cenderung menyesuaikan diri sebagai respons atas pengalaman selanjutnya, kepercayaan terhadap diri sendiri dengan mempertimbangkan setiap segi dari situasi yang dihadapi, perasaan bebas yaitu dengan memiliki perasaan berkuasa secara pribadi mengenai kehidupan dan percaya bahwa masa depan tergantung pada dirinya sendiri, kemudian sifat khas yang terakhir adalah kreativitas yang berarti bertingkah laku spontan, tidak defensif, berubah, bertumbuh, dan berkembang sebagai respons atas stimulus-stimulus kehidupan yang beraneka ragam di sekitarnya.

\section{PEMBAHASAN}

Tahapan perkembangan remaja seringkali diukur dengan berpatokan pada usia. Usia pada tahap remaja (adolescence) dimulai saat manusia berada pada masa puber dan berakhir pada usia 18 atau 20 tahun. Rentang usia remaja ini dapat dibagi menjadi dua bagian, yaitu usia 12/13 tahun sampai dengan 17/18 tahun adalah remaja awal, dan usia 17/18 tahun sampai dengan 21/22 tahun adalah remaja akhir [8]. Sedangkan Erickson membagi masa remaja menjadi tiga tahapan yakni masa remaja awal, masa remaja pertengahan, dan masa remaja akhir. Adapun kriteria usia masa remaja awal pada perempuan yaitu 13-15 tahun dan pada laki-laki yaitu 15-17 tahun. Kriteria usia masa remaja pertengahan pada perempuan yaitu 15-18 tahun dan pada laki-laki yaitu 17-19 tahun, sedangkan kriteria masa remaja akhir pada perempuan yaitu 18-21 tahun dan pada laki-laki 19-21 tahun [9]. Menurut Papalia \& Olds [7], masa remaja adalah masa transisi perkembangan antara masa kanak-kanak dan dewasa yang pada umumnya dimulai pada usia 12 atau 13 tahun dan berakhir pada usia akhir belasan tahun atau awal dua puluhan tahun. Disimpulkan bahwa masa remaja terbagi kedalam tiga tahapan yang masuk dalam rentan usia 12- 20 tahun, namun pada tahap remaja akhir ada ketidak jelasan usia, antara remaja akhir dengan dewasa awal dari usia yang dimiliki.Terpenting adalah ketika individu masuk dalam tahap remaja bukan ditentukan oleh usia, namun lebih kepada tugas perkembangan yang mampu dipenuhi oleh individu tersebut.

Tugas perkembangan remaja dipusatkan pada pusaka penanggulangan sikap dan pola perilaku yang kekanakkanakan dan mengadakan persiapan untuk menghadapi masa dewasa. Diantara tugas-tugas tersebut adalah menerima keadaan fisiknya, menggunakan tubuhnya secara efektif, mencapai kemandirian emosional dari orang tua dan orangorang dewasa lainnya, mengembangkan konsep keterampilan intelektual yang sangat diperlukan untuk melakukan peran sebagai anggota masyarakat, menerima dirinya sendiri dan memiliki kepercayaan terhadap kemampuannya sendiri, memperkuat self-control (kemampuan mengendalikan diri) atas dasar skala nilai, psinsip-psinsip, atau falsafah hidup dan meninggalkan reaksi penyesuaian diri (sikap/perilaku) kekanak-kanakan.Menurut Corey [3] sifat khas orang yang berfungsi penuh yaitu:

Terbuka pada pengalaman, berarti sesuai dengan tugas perkembangan remaja yaitu individu memiliki pengalaman sebagai tujuan untuk memperkuat self-control (kemampuan 
mengendalikan diri) atas dasar skala nilai, psinsip-psinsip, atau falsafah hidup. Kehidupan eksistensial sesuai tugas perkembangan yaitu menerima keadaan fisiknya, menggunakan tubuhnya secara efektif.

Kepercayaan terhadap diri sendiri sesuai tugas perkembangan yaitu menerima dirinya sendiri dan memiliki kepercayaan terhadap kemampuannya sendiri serta meninggalkan reaksi penyesuaian diri (sikap/perilaku) kekanak-kanakan.

Perasaan bebas sesuai tugas perkembangan yaitu mencapai kemandirian emosional dari orang tua dan orangorang dewasa lainnya.Kreativitas sesuai tugas perkembangan yaitu mengembangkan konsep keterampilan intelektual yang sangat diperlukan untuk melakukan peran sebagai anggota masyarakat.

Disimpulkan bahwa remaja yang memiliki fully human being adalah remaja yang mampu melaksanakan tugas-tugas perkembangannya. Hal ini sesuai dengan Rogers, [3] bahwa manusia memiliki kemampuan untuk membimbing, mengatur dan mengendalikan dirinya sendiri. Membimbing mengatur dan mengendalikan merupakan pembentukan identitas sebagai tahapan perkembangan yang telah diungkapkan oleh erikson [1]. Individu yang mampu membentuk identitasnya melalui pemenuhan diri dan beradaptasi dengan lingkungan berarti memiliki kesejahteraan psikologis [10]. Fully function being merupakan bagian dari kesejahteraan psikologis yaitu bagian dari dimensi psychological Well Being.

Banyak faktor-faktor yang mempengaruhi pencapaian fully human being yaitu salah satunya keluarga atau lingkungan sebagai bagian dari introyeksi, pribadi, dan mencapai prakarsa (sense of industry). Cara yang digunakan konselor untuk mengembangkan individu supaya mampu menjadi individu yang fully human being adalah dengan mengoptimalkan kemampuan invidu sebagai pribadi yang sehat sesuai teorinya Rogers. Rogers dalam membantu individu untuk mencapai pribadi yang sehat perlu memahami konsep dasar person center yaitu organisme, Medan fenomena, dan Self [3]. Self lebih mendekatkan dirinya kepada pembentukan fully human being, yaitu berupa terbentuk melalui medan fenomena dan melalui introjeksi nilai-nilai orang tertentu, menganggap pengalaman yang tak sesuai dengan struktur self sebagai ancaman, dan kematangan belajar.

Tujuan konseli dalam mencapai fully human being adalah mengubah perilaku yang salah, belajar membuat keputusan, dan mencegah timbulnya masalah. Orang tua sebagai pendidik terdekat dengan anak remajanya harus bisa menjadi individu yang ramah, penyayang, dan memberikan kebebasan kepada remaja untuk menunjukan prilaku, sikap, dan perasaannya. Supaya remaja mampu menjadi individu yang berfungsi penuh dengan memahami dirinya dan situasi yang dihadapi.

Individu yang mampu berfungsi penuh dapat tercapai melalui beberapa faktor salah satunya adalah penelitian yang dilakukan oleh Ryff \& Kyes [11] bahwa model teoritis kesejahteraan psikologis yang mencakup 6 dimensi yang berbeda dari kesehatan (Otonomi, penguasaan lingkungan, pertumbuhan diri, hubungan positif dengan lainnya, tujuan hidup, penerimaan diri). Disimpulkan bahwa remaja yang mampu berkembang dengan baik melaksanakan seluruh tugas perkembangannya, memiliki otonomi, tujuan hidup yang jelas, penguasaan lingkungan yang baik, serta memiliki hubungan yang positif dengan yang lain berarti dapat dikatakan bahwa individu tersebut memiliki kesejahteraan psikologis yang akhirnya masuk fully human being.

\section{KESIMPULAN}

Fully human being pada remaja sebagai pencapaian perkembangan identitas dapat diimplikasikan dalam kehidupan sehari-hari. Orang tua maupun pendidik terutama konselor memahami fully human being sebagai bagian dari teori person center. Remaja di hadapi dengan perasaan penuh empati, penerimaan, penghargaan, dan pemahaman sehingga remaja merasakan adanya kejujuran, keikhlasan, dan keterbukaan mengenai apa yang dihayati oleh konselor tentang konseli (remaja).

Perasaan penuh empati dirasakan dalam bentuk cerita yang disampaikan oleh remaja. Konselor menggunakan kemampuannya dalam menyadarkan konseli tentang seluruh kemampuan yang dimiliki konseli atau remaja itu sendiri tentang pengalaman, kualitas eksistensial, kepercayaan diri yang dimiliki, dalam mengembangkan kreatifitas melalui potensi-potensi yang dimiliki. Tujuannya jelas untuk memberikan kesempatan dan kebebasan kepada remaja dalam mengekspresikan perasaan-perasaannya. Hal itu disebabkan karena tahap perkembangan identitas, remaja ingin menjadi individu yang memperoleh kebebasan dan jati dirinya. Perlindungan dan peran serta dari lingkungan maka remaja dapat tumbuh dan berkembang menjadi individu yang positif dengan kemampuan dan potensinya.

\section{DAFTAR PUSTAKA}

[1] Santrock, John W. (2011). Perkembangan Anak Edisi 7 Jilid 2. (Terjemahan:Sarah Genis B). Jakarta: Erlangga.

[2] Santrock, J.W. (2007). Psikologi Pendidikan (edisi kedua). (Penerj. Tri Wibowo B.S). Jakarta: Kencana.

[3] Corey, G. (2009). Theory and Practice of Counseling and Psychotherapy. USA : Thomson Brooks/Cole.

[4] Lopez, \& Snyder, C.R. (2003). Positive Psychological Assessment a Handbook ofModels \&measures.Washington. DC : APA

[5] Gunarsa, D. Singgih. Yulia singgih D. Gunarsa. (2004). Psikologi Perkembangan Anak dan Remaja. Jakarta: Gunung Mulia.

[6] Hurlock, E.B. (2008). Psikologi Perkembangan: Suatu Pendekatan Sepanjang Rentang Kehidupan. Jakarta: Erlangga

[7] Jahja, Yudrik. (2012). Psikologi Perkembangan. Jakarta: Kencana

[8] Ali dan Asrori. (2006). Psikologi Remaja: Perkembangan Peserta Didik. Jakarta: Bumi Aksara

[9] Thalib, Syamsul Bachri (2010). Psikologi Pendidikan Berbasis Analisis Empiris Aplikatif. Jakarta: Kencana

[10] Garcia. (2014). The Affective Profiles Psychological Well Being and Harmony: Environmental Mastery and Self Acceptance Predict The Sense of A Harmonious Life. Journal Psycyatry and Psychology. Public Health

[11] Ryff \& Keyes. (1995). The Structure of Psychological Well-Being Revisited. Journal of Personality and Social Psychology. Vol. 69 No. 4 page $719-72$ 